\title{
Gender and Legislative Preferences: Evidence from the Argentine Provinces
}

\section{Tiffany D. Barnes}

\section{University of Kentucky}

When are underrepresented in most of the world's legislatures. multiple reasons, one of the central concerns of advocates and scholars rests on the assumption that women have different legislative preferences than their male counterparts. If this is the case, then it implies that where women do not occupy an equitable proportion of the legislature, their interests are not well represented.

On the other hand, there is reason to believe that the lack of female legislators may not be problematic for women's representation. Many scholars assume that all legislators have an electoral incentive to represent constituents' interests. This implies that, even if female legislators have different preferences, they will not behave differently than their male collogues. Given the divergent expectations of these two assumptions, scholars have developed a keen interest in understanding whether gender shapes legislative preferences and the extent to which it can be observed through legislative behavior.

I would like to acknowledge Mark P. Jones and Royce Carroll for their guidance and support on this project. I thank Miki Kittilson, Randy Stevenson, Jesse C. Johnson, Seonghui Lee, Jinhyeok Jang, Ben Saxton, and three anonymous reviewers for comments on earlier versions of this paper. I would like to thank CIPPEC, particularly Fernando Straface and María Marta Page, for assistance during my fieldwork in Argentina. I thank Carlos Gervasoni, Adrian Lucardi, Maria Paula Bertino, and countless Argentine bureaucrats and politicians for helping me arrange interviews and obtain data during my fieldwork. I gratefully acknowledge that this research was supported by the National Science Foundation Doctoral Dissertation Improvement Grant SES-0921374 and the Ora N. Arnold Fellowship.

Published by Cambridge University Press 1743-923X/12 \$30.00 for The Women and Politics Research Section of the American Political Science Association.

(C) The Women and Politics Research Section of the American Political Science Association., 2012 doi:10.1017/S1743923X12000505 
To assess these questions, multiple studies have used roll call voting to measure legislators' preferences. These analyses result in mixed findings. I argue that while male and female legislators are likely to exhibit distinct legislative preferences, roll call data's limitations make it difficult to assess gender differences. Legislative roll call voting is highly structured by party discipline, negative agenda control, and constituency influences. Consequently, few intraparty differences emerge in roll call data. Given these limitations, other types of political behavior that can be used to measure legislative preferences may be more useful for examining within-party differences.

Alemán et al. (2009) demonstrate that political scientists can measure legislative preferences by using cosponsorship data to recover ideal point estimates relatively comparable to those recovered from roll call voting. But, unlike roll call voting, cosponsorship activity is not structured by party discipline or negative agenda control (Talbert and Potoski 2002). As a result, cosponsorship data reveal significantly more intraparty variation and a higher dimensionality than roll call data. Thus, cosponsorship analysis may be a more useful tool for exploring how intraparty differences, such as gender, influence legislators' preferences. The goal of this research is to examine whether gender differences emerge when cosponsorship behavior is used to measure legislative preferences.

\section{GENDER AND ROLL CALL VOTING}

Despite significant gains over the past decade, women remain underrepresented in most of the world's legislatures. While there is a strong normative concern for electing representatives who reflect the demographics of a constituency, the implications of gender inequality in representative bodies extends far beyond the debate of descriptive representation. One of the chief concerns rests on the assumption that female legislators exhibit different legislative preferences than their male colleagues. These divergent legislative preferences influence how legislators govern and how they represent their constituents. If female legislators do, in fact, exhibit different preferences than men, then the disparity between the number of female and male legislators may indicate that women's interests are underrepresented.

This argument is based on the idea that historically marginalized groups have shared life experiences that give them different perspectives on a broad 
set of issues (Mansbridge 1999; Phillips 1995). In this view, members of these groups, or "descriptive representatives," may be better suited to represent their interests (Pitkin 1967). This is because personal traits (e.g., gender or race) may influence legislators' behavior "above and beyond the extent motivated by constituency and party pressures" (Bratton and Haynie, 1999, 659). This does not imply that all female legislators represent the same perspective, but rather that they represent a host of female perspectives that are distinct from their male colleagues (Piscopo 2011). Additional research supports the notion that female legislators are more likely to view women as an important and distinct piece of their constituency (Reingold 1992; Thomas 1997). Women elected via gender quotas may even feel a mandate or obligation to act on behalf of women (Franceschet and Piscopo 2008). As a result, many studies suggest that women's descriptive representation is a necessary component to represent female constituents.

On the other hand, there is reason to believe that female legislators may not represent women differently. This argument is based on rationale that the primary objective of all legislators is reelection (or advancing one's political career). Regardless of their sex, all legislators have an incentive to represent their district's interests (Mayhew 1974). Female legislators, by implication, will not represent constituents differently than their male colleagues, and gender differences will not be observable via legislative behavior. Given these opposing expectations, scholars of gender and politics have developed an interest in understanding whether gender shapes legislative preferences.

Over the past few decades, analyses of roll call voting have become standard for measuring legislative preferences. These analyses rely on multiple different scaling techniques (e.g., Clinton, Jackman, and Rivers 2004; Londregan 2000; Martin and Quinn 2002; Poole 2000; Poole and Rosenthal 1991; 1997) as well as various interest group scores (e.g., Americans for Democratic Action and the American Conservative Union) to determine legislators' preferences in relation to one another. As a result, numerous studies have used roll call voting to examine the extent to which female legislators exhibit different preferences than male legislators. Yet findings from roll call voting analyses are mixed. Several studies find that gender affects voting patterns of female legislators (Burrell 1994; Clark 1998; Frankovich 1977; Hogan 2008; Leader 1977; Welch 1985). But others find no, or only qualified, support for gender differences (Barnello 1999; Schwindt-Bayer and Corbetta 2004; Thomas 1989; Vega and Firestone 1995). 
Schwindt-Bayer and Corbetta (2004) argue that one reason previous research has delivered mixed findings is because most research designs do not properly account for constituency characteristics. While they grant that women may be more liberal than men, they suggest that more liberal roll call voting patterns result among women because they are often elected in more liberal districts. Moreover, district characteristics are difficult to account for using conventional control variables. They employ a research design that relies on legislative turnover to hold constituency characteristics constant across legislators and find no gender differences in roll call voting.

Studies that limit the analysis to roll call votes on women's issues also result in mixed findings. Some find that gender is a significant predictor of vote choice (Tatalovitch and Schier 1993), and that women are more likely to vote together across party lines (Swers 1998; 2002). For example, Swers finds that Republican women are particularly more likely to defect from the party line to support women's issues in the U.S. Congress. In a study with a similar research design, though, Barnello (1999) shows that such is not the case for the New York State Assembly. In sum, previous research that uses roll call voting to measure legislative preferences finds, at best, mixed support for the hypothesis that women display different preferences than their male colleagues.

\section{THE DRAWBACKS TO ROLL CALL DATA}

While there is considerable reason to believe that men and women have different legislative preferences, there are grounds to believe that roll call voting may not be the best place look for gender differences among legislators (Norton 1997; Poggione 2004; Schwindt-Bayer and Corbetta 2004). First, a number of studies rely on interest group scores to examine gender differences in legislative preferences. But Norton (1997) shows that interest group indices often exclude votes of particular interests to women. The exclusion of key votes makes it unlikely that gender differences will emerge.

Second, roll call voting is highly structured by negative agenda control. Legislative institutions give party leaders control over which bills come up for a vote. Since party leaders have an incentive to protect the party brand name, it is rare that they permit legislation that divides the governing party to come to a vote on the floor (Cox and McCubbins 2005). Thus, roll call 
voting does not reveal information about the full range of legislators' preferences, but rather only shows where they stand on a small set of issues - issues that do not divide the majority party. Even in legislative chambers where legislators come under the pressure of multiple factions within the party, leadership can mitigate conflict within the party by negotiating policy outcomes before legislation is brought to a vote. Federalism, for example, can divide or weaken national level parties (Chhibber and Kollman 1998; Mainwaring 1999). In Argentina, for instance, provincial-level party leaders have considerable control over legislators' career prospects, causing legislators to have a stronger incentive to represent the interests of provincial party leaders than those of national party leaders (Jones 2008). Nevertheless, such divisions do not diminish party voting unity because the governing party uses negative agenda control to keep issues that divide the party from coming to a floor vote (Carey 2009; Desposato 2004; Jones and Hwang 2005a). As a result, negative agenda control makes it difficult to identify divisions within political parties via roll call voting analyses.

Third, it is difficult to identify intraparty differences because roll call votes are highly structured by party discipline. Individual votes are typically decided by the party as a whole, and members are expected to represent the party's preference, not their own. Party discipline is particularly strong outside of the United States. ${ }^{1}$ For example, in an analysis of 15 countries, Carey (2009) explains that in most legislative chambers in Latin America, roll call votes are a matter of party discipline, and legislators who break discipline are typically sanctioned. Thus, roll call data strongly reflect partisan divisions and provide little information about the intraparty relationship between legislators.

The combination of negative agenda control and high party discipline results in roll call behavior that is highly polarized and exhibits low dimensionality. Although the large majority of research on roll call behavior focuses on the U.S. Congress, low-dimensional spatial models have been found in a wide variety of settings, including the United Nations, multiple countries across Europe, and all throughout Latin America (Carey 2009; Poole and Rosenthal 2001). Findings from Argentina are consistent with the broader literature on roll call data. In

1. In the United States, context roll call voting is highly ideological and, thus, appears as though it may be governed by party discipline. McCarty, Poole, and Rosenthal (2001) argue that while party is an extremely strong predictor of legislators' ideal points, less clear is the extent to which legislators' positions are a product of party discipline or ideological discipline, electoral pressures, and other external pressures. 
Jones and Hwang's (2005a) detailed roll call analysis of the Argentine National Congress, an average of $93.2 \%$ of bills are correctly classified by the first (i.e., partisan) dimension. Given the small number of roll call votes in Argentina, this means that there were never more than 11 votes that were incorrectly classified, but more frequently there were as few as one or two (see Table 1 in Jones and Hwang 2005a). To account for the small number of bills that were not correctly classified by the partisan dimension, Jones and Hwang labored over newspapers, parliamentary debates, and personal interviews with deputies to identify any discernible commonalities in these bills. They conclude that, "no conceivable second dimension was detected" (2005a: 271). Given the highly polarized and low-dimensional properties of roll call behavior, even if

Table 1. Intra partisan gender differences in legislators' ideal point estimates, estimated coefficients from HLM using the pooled sample

\begin{tabular}{|c|c|c|}
\hline & $\begin{array}{c}\text { Model (1): } \\
\text { First Dimension }\end{array}$ & $\begin{array}{c}\text { Model (2): } \\
\text { Second Dimension }\end{array}$ \\
\hline Female & 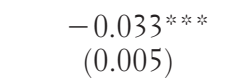 & 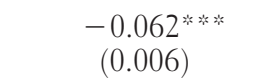 \\
\hline$\%$ Women & $\begin{array}{c}0.021 \\
(0.216)\end{array}$ & $\begin{array}{c}-0.359 \\
(0.221)\end{array}$ \\
\hline GDI & $\begin{array}{c}-1.490 \\
(1.526)\end{array}$ & $\begin{array}{r}-2.368 \\
(1.464)\end{array}$ \\
\hline GDP & $\begin{array}{c}0.244 \\
(0.435)\end{array}$ & $\begin{array}{c}0.367 \\
(0.426)\end{array}$ \\
\hline At-large & $\begin{array}{c}0.003 \\
(0.052)\end{array}$ & $\begin{array}{c}0.007 \\
(0.049)\end{array}$ \\
\hline Constant & $\begin{array}{l}1.500 \\
(1.190)\end{array}$ & $\begin{array}{l}2.354 * * \\
(1.139)\end{array}$ \\
\hline \multicolumn{3}{|c|}{ St. Dev. of the Random Effects Intercepts } \\
\hline Chamber-level & 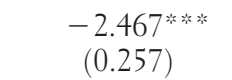 & 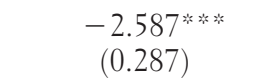 \\
\hline Session-level & 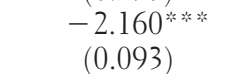 & 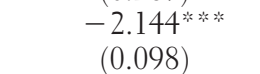 \\
\hline Legislator-level & 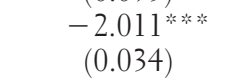 & 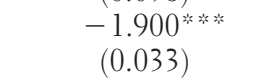 \\
\hline St. dev. residual & $\begin{array}{l}-1.334^{\text {* }} \\
(0.007)\end{array}$ & 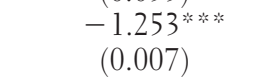 \\
\hline Chambers & 18 & 18 \\
\hline Sessions & 118 & 118 \\
\hline Legislator-dyads & 12,259 & 12,259 \\
\hline
\end{tabular}

Notes: Coefficients from HLM and pooled sample. Standard errors in parentheses. The dependent variable for Model 1 (Model 2) uses ideal point estimates from the first dimension (second dimension). Levels of significance: ${ }^{*} \mathrm{p}<.10$; ${ }^{* * *} \mathrm{p}<.01$; ${ }^{* * * *} \mathrm{p}<.001$. 
gender differences do exist, we may not expect to see them emerge in roll call voting.

Finally, roll call analysis poses practical problems for researchers looking beyond the U.S. Congress (Carey 2009). Many legislatures do not record roll call votes at all, making it impossible to use roll call analysis. Other chambers only record votes when a member formally requests a recorded vote. Selectively recording votes creates a biased sample. Collectively, the qualities of roll call votes discussed in this section may explain why previous research has produced inconsistent evidence that gender influences legislative preferences.

\section{COSPONSORSHIP ANALYSIS: A POSSIBLE ALTERNATIVE}

Given the challenges posed by roll call analysis, scholars of gender and politics have advocated looking beyond roll call analyses to uncover gender differences in policy preferences (Norton 1997; Poggione 2004). Similarly, recent literature has begun to explore how different types of legislative behavior, such as cosponsorship activity, can be used to examine legislative preferences (e.g., Alemán el al. 2009; Talbert and Potoski 2002). In a recent study, Alemán et al. (2009) demonstrate that political scientists can measure legislative preferences using cosponsorship data to recover ideal point estimates relatively comparable to those recovered from roll call voting. But, unlike roll call voting, cosponsorship activity is not structured by party discipline or negative agenda control (Talbert and Potoski 2002). As a result, cosponsorship data reveal significantly more intraparty variation than roll call data and may be better suited for exploring more subtle intraparty differences. Accordingly, I use cosponsorship data to explore whether women exhibit different legislative preferences than men. Before proceeding with the analysis, though, it is necessary to identify the advantages and disadvantages of using cosponsorship data to measure preferences as well as what I mean by legislative preferences with respect to cosponsorship data.

Cosponsorship analysis has substantial merits. The first benefit is that cosponsorship activity is not subject to negative agenda control. Legislative rules enable party leaders to reduce a multidimensional issue space into one-dimensional roll call votes via negative agenda control (e.g., Shepsle 1979). Conversely, legislative rules do not allow party leaders to monitor formally and restrict what legislation is introduced. 
Instead, legislators are relatively free to decide what legislation to introduce and with whom to cosponsor it. Prefloor decisions, such as cosponsorship, reflect a higher dimensionality and more intraparty variation than roll call votes (Talbert and Potoski 2002).

The second benefit is that cosponsorship activity is not governed by strong party discipline. In many chambers, legislators are required to vote in lock step with the party. This limits the amount of useful information scholars can extract from roll call votes. Cosponsorship data remedy this problem by providing more intraparty information. Party leaders have relatively little incentive to exercise party discipline over bill cosponsorship for two reasons (Highton and Rocca 2005). First, cosponsorship activity is not deterministic of policy outcomes. Most bills never come to a vote. So, it is more costly for party leaders to exercise party discipline in the prefloor stage than to use institutional rules to prevent bills from advancing to the floor. Second, bill cosponsorship is less likely than roll call voting to affect adversely the party brand name. News media and opposition campaigns tend to draw more attention to a legislator's voting record than the member's cosponsorship record (Sulkin and Swigger 2008). Since partisan and constituent pressures impose less structure on cosponsorship activity, cosponsorship analyses uncover more dimensions than do roll call vote analyses, particularly in chambers with strong party discipline (Alemán et al. 2009).

Additionally, cosponsorship analyses have practical benefits. Cosponsorship data allow scholars to recover legislators' policy positions in chambers where roll call voting is not well recorded or not recorded at all (as is the case in the Argentine provinces and many developing democracies) (Carey 2009). Moreover, scholars can measure cosponsorship behavior with practically no error.

Despite these advantages, cosponsorship data also have shortcomings. First, cosponsorship is a voluntary activity. Unlike roll call voting, where all members vote on the same issues, representatives must pick and choose which legislation they will cosponsor (Highton and Rocca 2005). While roll call votes provide information about every member on every issue that comes to the floor, cosponsorship data only provide information about some members on some issues. When a representative chooses to cosponsor legislation, this activity provides a large amount of information about the legislator vis-à-vis other legislators, and it sends a clear signal that the representative supports the proposed policy location over the status quo. But when a legislator does not cosponsor, there is no information about the representative's position. It is not clear what it 
means for a representative to refrain from cosponsoring. Not cosponsoring may signal that a representative is opposed to, not interested in, or simply not aware of the proposed legislation. Scholars cannot distinguish between the intentions of representatives who do not cosponsor and, therefore, treat all choices not to cosign the same (Alemán et al. 2009).

Second, some scholars question the amount of information that can be obtained from cosponsorship data because they are essentially "cheap talk" (Fowler 2006, 459). Representatives who cosponsor legislation do not have to spend time drafting legislation; they just sign on. Cosponsorship is a lowcost way to signal one's position on issues (Kessler and Krehbiel 1996; Wilson and Young 1997). Cosponsorship cannot "reveal the depth of members' commitment" to issues (nor can roll call voting), but it is still a good indicator of their general interests (Swers 2002, 57).

Ultimately, the strengths of cosponsorship data outweigh the weaknesses, I argue, because one of the most fundamental ways to think about cosponsorship is as a tool for legislators to signal their preferences to their colleagues and constituents. Cosponsoring legislation is a relatively lowcost activity legislators can use to take positions on important issues (Balla and Nemacheck 2000; Campbell 1982; Highton and Rocca 2005; Koger 2003; Krehbiel 1995; Mayhew 1974; Swers 2002). Crisp, Kanthak, and Leijonhufvud (2004) explain that the coauthors with whom a legislator collaborates may be just as important as the subject matter of legislation for signaling the legislator's preferences. Legislators can use cosponsorship activity to make themselves appear more similar to some colleagues while distinguishing themselves from others. As such, whom a legislator coauthors with may be even more informative than the content of the legislation. Along a similar vein, Alemán et al. (2009) measure legislative preferences using cosponsorship data to recover ideal point estimates. They rely only on the cosponsorship coalitions - not the content of legislation - to determine legislators' positions. Unlike previous literature that examines women's preferences by examining whether women sponsor and cosponsor legislation that is of particular interest to women (e.g., Schwindt-Bayer 2010; Swers 1998, 2002), their analysis of cosponsorship data allows us to understand representatives preferences vis-à-vis other representatives.

One difference is that, unlike ideal point estimates recovered from roll call votes, cosponsorship analysis results in a higher dimensionality (Alemán et al. 2009; Talbert and Potoski 2002). While the first dimension represents the primary cleavage in a legislature (e.g., often the partisan cleavage), other dimensions can be thought of as salient issue 
cleavages within the chamber. Taken together, when I refer to legislative preferences, I am examining if women exhibit distinguishable policy preferences from men, which manifest in distinct cosponsorship coalitions.

\section{SAMPLE SELECTION AND RESEARCH DESIGN}

This analysis uses cosponsorship data from 18 provincial legislative chambers in Argentina from 1994 to 2009. Subnational institutions in federal systems merit scholarly attention - particularly from those scholars studying gender and politics - because subnational governments typically have jurisdiction over health and education policies. As Franceschet (2011) points out, this jurisdiction gives state governments influence over areas of reproductive rights, access to contraceptives, sexual education, and other issues that shape women's lives. For these reasons, I choose to examine whether gender influences legislative preferences in Argentine provincial legislatures. The Argentine provinces also provide an ideal setting to examine whether female representatives exhibit different preferences than their male colleagues.

First, in many of the Argentine legislatures, representatives are elected from at-large electoral districts. At-large districts are advantageous because they allow me to hold district and constituency characteristics constant across legislators. Previous research argues that, first, it is extremely difficult to control for constituency and district influences and that, second, previous finding of gender differences in roll call voting may be due to the lack of adequate controls (Schwindt-Bayer and Corbetta 2004). I hold district and constituency constant by examining legislative behavior in at-large districts and multimember districts. Specifically, 11 of the chambers in my sample use at-large districts to elect provincial legislators (see Table 2). The district sizes range from 14 members in the at-large district in Santa Cruz to 66 members in the Córdoba House. Together, the districts have an average of 36 seats per district. The remaining six chambers have multimember districts (ranging from 3 to 18). At-large districts and multimember districts allow me to compare legislative preferences of male and female legislators who were elected in the same district.

Second, the vast majority of the Argentine provinces have adopted a legislative gender quota. The quotas require that women occupy at least $30 \%$ of the candidate list for all political parties participating in 
Table 2. Sample selection and summary of results from chamber-level analyses

\begin{tabular}{|c|c|c|c|c|c|c|c|c|}
\hline \multirow[t]{2}{*}{ Legislative Chamber } & \multirow[t]{2}{*}{ Years in Sample } & \multicolumn{2}{|c|}{ Percent Women } & \multicolumn{2}{|c|}{ Dimension } & \multicolumn{2}{|c|}{$\begin{array}{c}\text { Proportion of } \\
\text { Variance } \\
\text { Explained }\end{array}$} & \multirow[t]{2}{*}{ District Type } \\
\hline & & Average & Range & First & Second & First & Second & \\
\hline Buenos Aires House & $1996-2009$ & 24 & $11-30$ & $*$ & * & 0.42 & 0.14 & Multimember \\
\hline Buenos Aires Senate & $1996-2009$ & 23 & $16-28$ & * & $*$ & 0.59 & 0.15 & Multimember \\
\hline Córdoba Senate & $1996-2003$ & 16 & $8-31$ & & $*$ & 0.35 & 0.17 & Multimember \\
\hline Mendoza House & $1994-2009$ & 21 & $15-25$ & $*$ & $*$ & 0.24 & 0.13 & Multimember \\
\hline Mendoza Senate & $1994-2009$ & 19 & $13-24$ & * & * & 0.31 & 0.16 & Multimember \\
\hline Salta House & $1996-2009$ & 18 & $12-27$ & & * & 0.43 & 0.16 & Multimember \\
\hline Tucumán & $1996-2009$ & 19 & $13-23$ & & * & 0.35 & 0.17 & Multimember \\
\hline Córdoba Unicameral & $2004-2009$ & 32 & $27-34$ & * & * & 0.40 & 0.16 & Mixed with at-large \\
\hline Río Negro & $1996-2009$ & 29 & $21-38$ & * & * & 0.49 & 0.18 & Mixed with at-large \\
\hline Santa Cruz & $1994-2009$ & 14 & $5-22$ & * & & 0.76 & 0.10 & Mixed with at-large \\
\hline Chaco & $1994-2009$ & 27 & $18-38$ & $*$ & * & 0.48 & 0.17 & At-large \\
\hline Chubut & $1996-2009$ & 31 & $30-33$ & & & 0.47 & 0.19 & At-large \\
\hline Córdoba House & $1996-2003$ & 27 & $23-30$ & & $*$ & 0.36 & 0.13 & At-large \\
\hline Corrientes House & $1994-2009$ & 22 & $8-39$ & & * & 0.49 & 0.20 & At-large \\
\hline Federal District & $1998-2009$ & 33 & $33-33$ & $*$ & * & 0.35 & 0.16 & At-large \\
\hline Formosa & $1996-2009$ & 29 & $13-33$ & $*$ & $*$ & 0.45 & 0.17 & At-large \\
\hline Misiones & $1996-2009$ & 27 & $23-30$ & * & * & 0.65 & 0.15 & At-large \\
\hline Santa Fe House & $1996-2009$ & 27 & $26-28$ & * & * & 0.40 & 0.14 & At-large \\
\hline
\end{tabular}

Notes: The fifth and sixth columns (Dimension, First and Dimension, Second) summarize the findings from the chamber-level analyses. The results presented in these two columns are based on a HLM that uses ideal point estimates from the first dimension (second dimension) to calculate the dependent variable. An asterisk indicates the results for the coefficient "female-female dyad" are in the expected negative direction. Bold-faced asterisks indicate significance at p <.10 in a one-tailed test. Santa Cruz, Río Negro, and Córdoba Unicameral employ mixed-member electoral systems. In these districts, a portion of the members are elected from single member districts (as is the case in Santa Cruz and Córdoba Unicameral) or small multimember districts (Río Negro) and the rest of the legislators are elected from one at-large district. These analyses include only members elected in the at-large district in order to hold constituency variables constant. 
legislative elections. The ubiquitous adoption of legislative gender quotas ensures that women are elected in all districts and also that they represent all legislative parties. Since the electoral law requires that every party in every district complies with the gender quota to compete in the election, women are not more likely to be elected in more liberal districts or by more woman-friendly parties. ${ }^{2}$ Gender quotas in at-large districts, therefore, allow me to compare the preferences of women and men who represent the exact same constituency. Consequently, if only constituency and/or partisan influences shape legislators' preferences, then women will behave no differently than men. But if personal traits, such as gender, do have an impact, then gender differences will emerge. For this reason, my analysis only includes chambers that have adopted gender quotas, and the period of analysis in each chamber begins after the implementation of the quota.

I traveled to each of the provinces in my sample to interview legislators, conduct archival research, and observe legislative sessions. ${ }^{3}$ In every province, legislators and legislative observers described the same voting process. Legislators meet with their political parties in the reunión del bloques prior to floor votes to determine the party's position. On the chamber floor, all party members vote the same way. The provincial legislatures do not systematically record roll call legislation. Members simply raise their hands to signal their position, and only the final outcome is recorded. Elite political observers often noted that, when voting, legislators do not think for themselves; they simply raise their hands when they are told to do so.

If a member disagrees with the party position, then the legislator may abstain from voting (which is rare) or risk party sanctions. Legislators who break with the party line are typically removed from the party or voluntarily leave the party. Since provincial party bosses largely determine the career patterns of Argentine politicians, breaking from the party typically means the end of a member's political career (Jones 2008). Thus, members rarely have an incentive to defect. ${ }^{4}$ Given the strong party discipline that governs legislative voting in the Argentine

2. Placement mandates ensure that every party in the provincial level election complies with the gender quota. Not every province, however, adopted placement mandate language when quotas were first adopted. Some provinces adopted the placement mandate language in a later legislative session. In my sample, this is the case for Buenos Aires, Córdoba, Corrientes, Mendoza, Río Negro, and Tucumán.

3. While in Buenos Aires, I interviewed legislators from Santa Cruz. I did not travel there.

4. There are very few exceptions to this structure of roll call voting. On rare occasions, contentious votes are considered an issue of "conscience." If the chamber votes on an issue of conscience, then members 
provinces, gender differences would certainly not be detectable via roll call behavior (even if it were recorded). Rather, roll call behavior in the provinces would look very similar to roll call behavior in the National Congress. Recall that roll call analyses at the national level indicate that the Argentine Congress can be characterized by a single partisan dimension (Jones and Hwang 2005a). Further, additional analyses of roll call data from the Argentine Congress do not uncover any gender differences. ${ }^{5}$ The strong party discipline and negative agenda control that constricts the information available from roll call voting and the absence of record votes (a limitation common across Latin America [cf. Carey 2009]) further illustrates the need to examine prefloor behavior, such as cosponsorship analysis, in effort to discern gender differences in legislative preferences.

\section{IDEAL POINT ESTIMATES USING COSPONSORSHIP DATA}

The first step in my empirical analysis is to calculate ideal point estimates using cosponsorship data. ${ }^{6}$ I employ the technique developed by Alemán et al. (2009). I first code the cosponsors of each piece of legislation authored during the period under study. For each piece of legislation, a representative receives a " 1 " if he/she coauthored the legislation and a "0" otherwise. Second, I use this information to construct an affiliation matrix. This indicates the number of times each pair of legislators coauthor together. For example, in 2002 in the Córdoba Chamber, María Amelia Chiófalo and María del Carmen Ceballos de Carbonetti coauthored 17 bills together. The affiliation matrix reflects this information for each legislator dyad in the chamber. Then, I use the affiliation matrix to calculate an agreement matrix. The agreement

are permitted to vote as they personally see fit. These issues are few and extremely controversial. Consequently, they rarely come to a vote (on average no more than one or two per session).

5. I obtained replication data from Jones and Hwang (2005a) to examine whether gender differences emerge in their roll call data. I do not find evidence of gender differences. I also obtained replication data from Alemán et al. (2009) to examine whether gender differences emerge when analyzing cosponsorship data in the Argentine National Congress. Using the exact same sample of representatives, I find that gender differences do emerge in the cosponsorship analysis of Argentina, but not in roll call analysis. These findings can be explained by the fact that, as Jones and Hwang demonstrate, roll call data in the Argentine Congress is highly structured by party discipline and negative agenda control. Yet cosponsorship data reveals more intraparty differences (Alemán et al. 2009).

6. The cosponsorship data are based on an original dataset that I collected by visiting each legislative chamber between August 2009 and May 2010. With the exception of Santa Cruz, data were obtained from the parliamentary services or the legislative archives in the provincial legislatures. Data for Santa Cruz were collected from the online archive in December 2009. 
matrix indicates the ratio of legislation each legislator-dyad cosponsors together to the total number sponsored by each of them. Consider, for example, Diputada Chiófalo, who coauthored 46 bills. Seventeen (or $37 \%$ ) of them were with her colleague Diputada Ceballos de Carbonetti. Diputada Ceballos de Carbonetti coauthored a total of 52 bills, though; so, only $33 \%$ of her bills (i.e., 17/52) were coauthored with Diputada Chiófalo. Finally, I use a principal component analysis with singular value decomposition to recover ideal point estimates from the logtransformed agreement matrix. Singular value decomposition is a way of factoring matrices into a series of linear approximations that expose the underlying structure of the matrix (or that best explain the variance in the data). As a result, when two members coauthor together frequently, their ideal point estimates will likely be more similar than coauthors who rarely work together. Hence, Diputada Chiófalo's ideal point estimate on the first dimension (.67) is closer to Diputada Ceballos de Carbonetti's (.46), with whom she coauthored 17 bills and has an agreement score of $37 \%$, than it is to Diputado José Tanus Rufei's (.28), with whom she coauthored 4 bills and has an agreement score of $9 \%$. I recover the ideal point estimates for the first two dimensions. ${ }^{7}$

Plots of the ideal point estimates reveal that, similar to the National Argentine Chamber of Deputies, the provincial legislatures in Argentina are organized along a government vs. opposition continuum, which can be interpreted as a partisan index. As an illustration of this pattern, Figure 1 plots the ideal point estimates recovered from first and second dimensions from the Unicameral Chamber in Córdoba from the 2002-2003 period. During this period, two political parties controlled the Chamber of Deputies: the Partido Justicialista (PJ - the governing party) and Unión Cívica Radical (UCR). ${ }^{8}$ As Figure 1 illustrates, this interparty dynamic largely explains the first dimension. There is relatively high and

7. See Alemán et al. (2009) for a detailed discussion of the method employed here. Alemán et al. (2009) compare cosponsorship analysis between the U.S. Congress and the Argentine Congress. These chambers exhibit different cosponsorship behavior in terms of the size of cosponsorship coalitions. There are a number of ways one could create comparability between the two chambers. For example, they use a log transformed agreement matrix for the Argentine Congress and an agreement matrix without a log transformation for the U.S. Congress. There is similar variation in the cosponsorship patterns of the Argentine provinces. In some provinces, it is common for members to form small cosponsorship coalitions (two to five members). In other provinces, it is not uncommon that whole parties mobilize to coauthor legislation together (20 to 30 members). Since party level decisions to cosponsors bills are not consistent with the underlying assumptions of the research and do not reveal intraparty differences, in addition to using the log transformed agreement matrix, the results presented here omit bills coauthored by nearly the whole chamber or those coauthored by the vast majority of the dominant parties. The results are robust to this decision.

8. In 2002 in Córdoba, the PJ was part of the Alliance for the Union of Córdoba. 


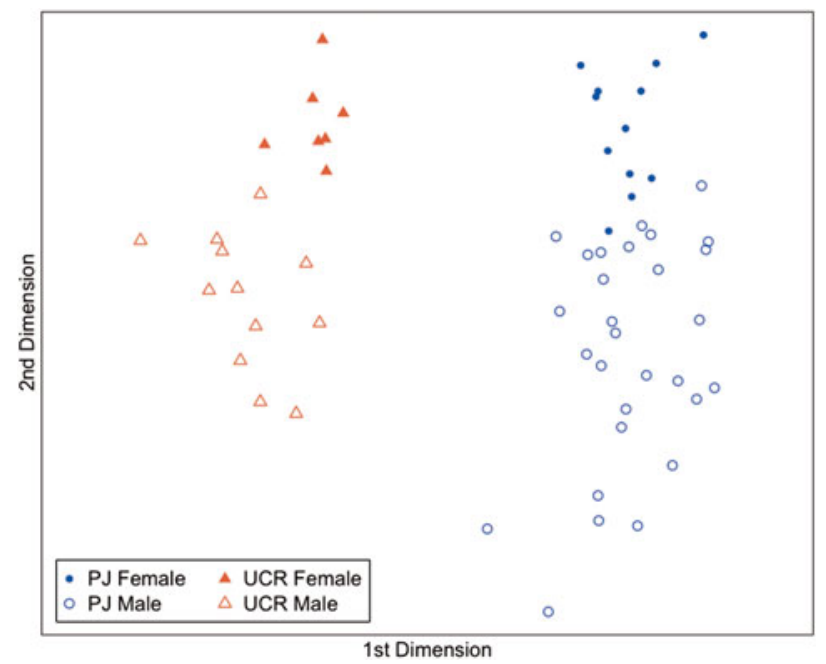

Figure 1. Scatter plot of ideal point estimates obtained from cosponsorship data: example from the Unicameral Chamber of Deputies in Córdoba 2002-2003.

stable interparty heterogeneity in legislators' cosponsorship behavior. This is exemplified by the division in ideal point estimates between parties and the relatively limited intraparty variation on the first dimension.

During this legislative period in Córdoba, the first dimension only explains .40 of the variance in cosponsorship behavior. The second dimension explains an additional .16 of the variance. Given the relatively unstructured nature of cosponsorship behavior, the significant proportion of variance explained by the second dimension (relative to analyses of roll call voting) is not surprising. It is consistent with the discussion of cosponsorship behavior, and it provides evidence that the second dimension merits attention. Whereas the first dimension in this plot illustrates a sharp partisan divide, the second dimension illustrates more intraparty heterogeneity. The second dimension represents salient issue cleavages within the political parties. While multiple issue cleavages (e.g., social or regional) may arise within the parties, this research is primarily focused on identifying gender differences. The plot clearly shows that gender differences emerge in the second dimension. The ideal point estimates for the PJ and the UCR demonstrate that women tend to have more similar preferences to their female copartisans than to their male copartisans. This difference is evident from the way that female legislators cluster on the north end of the plot. 
The clustering of ideal point estimates represents the propensity of women to work together in an effort to introduce legislation that raises awareness around social issues; and it highlights their tendency to coauthor important legislation for women, children, and families. For example, in 2000, ten women from the Córdoba Chamber of Deputies coauthored legislation to create the Provincial Council of Women. The goal of the agency is to bring together a range of political actors to promote women's rights. While ten women initially created the agency, the coalition of actors who influenced the development of the council grew to include the vast majority of female legislators. In 2002, 23 women coauthored legislation amending the structure of the council's executive bureau. This is only one of the 25 bills in the Córdoba Chamber in 2002 that was coauthored by a coalition of five or more women.

Consistent with the example from Córdoba, in most of the legislative chambers in my sample, the first dimension reflects sharp partisan divisions. Interviews with representatives in all chambers suggest that it is rare for legislators to seek out a coauthor from the opposition party, and this norm is clearly reflected in the data. The second dimension tends to reveal more intraparty variation, which indicates that gender differences may be more likely to emerge here.

\section{MEASURING GENDER DIFFERENCES: THE DEPENDENT VARIABLE}

In this section, I use the ideal point estimates to measure differences between women's and men's legislative preferences, particularly within political parties. Therefore, I only evaluate differences between members from the same political party. I measure the dependent variable by taking the absolute value of the dyadic difference between each female legislator's ideal point and each of her copartisans. This allows me to measure whether women's preferences are closer to their female copartisans than they are to their male copartisans.

This measurement is particularly appropriate for the Argentine context. Like many political party systems in Latin America, Argentine political parties do not have strong ideological differences and do not exhibit stable policy preferences over time (De Riz 1996; Gibson and Calvo 2000; Manzetti 1993). Rather, Jones and Hwang (2005a) characterize the National Chamber as being organized along government vs. opposition continuum. While this can be interpreted as a partisan index, 
the left-right ordering of the parties cannot be directly interpreted as liberalconservative. Political parties, in other words, do not consistently occupy the same ideological position from year to year, from province to province, or even from legislator to legislator within the same chamber (Jones and Hwang 2005b). For example, Barnes and Jones (2011) point out that in the past two decades, presidents from the Partido Justicialista have occupied multiple ideological positions (i.e., President Menem [conservative, 1989-1999], President De la Rúa [centrist, 2000-2001], President Kirchner [progressive, 2004-2007], and President Fernández [progressive, 2008-present]). Similarly, Jones and Hwang use elite survey data to demonstrate that Congress members from the main Argentine parties (i.e., the PJ and the UCR) are often "indistinguishable in terms of their ideological self-placement" despite the fact that their voting behavior on the floor is "quite distinct and polarized" (2005b, 133). By contrast to the U.S. Congress, political party affiliation in Argentina is not indicative of a representative's ideology. Moreover, Argentina is unique in that a large number of political parties compete in only one province (De Luca, Jones, and Tula 2002). These characteristics of the Argentine political party system make it impossible to develop expectations about how female legislators will differ from male legislators on a left-right continuum or to apply one expectation to all provinces.

I can, however, assume that legislators who are located close to one another on a given dimension are more similar than legislators who are located further apart. Therefore, I measure gender differences as the absolute value of the difference between each female legislator and each of her copartisans (i.e., |ideal point $\mathrm{L}_{\mathrm{L}}$-ideal point $\mathrm{L}_{\mathrm{L} 2} \mid$ ). The theoretical distance ranges from 0 to 2 . It is worth repeating that I am only interested in gender differences within political parties, so I limit my analysis to copartisan dyads. If gender differences do exist within parties, then the average distance between female-female dyads will be smaller than the difference between female-male dyads. Since the first dimension reflects a sharp partisan divide and the second dimension reveals more intraparty variation, I examine both dimensions.

\section{ESTIMATION TECHNIQUE}

To determine whether a gender difference exists between these two groups (i.e., female-female dyads compared to female-male dyads), I regress the 
gender composition of the dyad onto my dependent variable. This variable labeled Female is coded "l" for female-female dyads and " 0 " for femalemale dyads. Since my sample selection holds district and constituency characteristics constant for all legislators in the same legislative session and only compares copartisans, I do not need to control for these variables. Still, there is variation across legislative chambers and within legislative sessions. For example, one may think that the status of women within the province or the legislative chamber may influence women's behavior. To account for this variation, I control for the percentage of women in the legislative chamber during each session, the economic development of the province (measured as GDP), and the Genderrelated Development Index (GDI) in each province. It is also possible that different electoral rules influence the way representatives behave, so I control for the type of district used to elect members (i.e., multimember or at-large).

Given the structure of my data (i.e., there are three levels: dyads nested within legislators, legislators nested within sessions, and sessions nested within chambers), I estimate this relationship using a hierarchical linear model (Gelman and Hill 2007). I include three random intercepts, one for each level in the data: individual legislators, legislative sessions, and legislative chambers. The inclusion of a random intercept relaxes the assumption of independence of errors for observations within the same level. Omitting the random intercepts would produce biased standard errors, potentially biasing the results in favor of gender differences. The results for the pooled analysis are reported in Table 1.

\section{DO GENDER DIFFERENCES EXIST?}

Turning first to Model 1 in Table 1 , we see the average distance between female-female dyads compared to the average distance between femalemale dyads using ideal point estimates obtained from the first dimension. In the pooled analysis, the coefficient for female-female dyad $(-.033)$ is negative and significant. This means that, on average, the ideal point estimates of women are closer to the ideal point estimates of their female copartisans than they are to the ideal point estimates of their male copartisans, signifying that the preferences exhibited by female legislators are more similar to other women. The analysis indicates that gender differences emerge in the first dimension. 
The second dimension reveals more intraparty heterogeneity and explains, on average, an additional .16 of the variation in cosponsorship behavior. Model 2 in Table 1 reports the results for the analysis of the second dimension. First, notice the size of the coefficient for the constant (2.354). This indicates the average distance between female and male representatives from the same party. The coefficient is much larger than the constant reported for Model 1 (1.500). The larger coefficient indicates that the average distance between female and male copartisans is larger on the second dimension than it is on the first, providing further evidence that the second dimension exhibits more intraparty heterogeneity. Next, look at the coefficient for Female $(-.062)$. Similar to the first dimension, the negative coefficient indicates that female legislators exhibit preferences that are more similar to their female colleagues than to their male colleagues. Moreover, the coefficient is about double the size of the coefficient reported in Model $1(-.033)$. The larger coefficient indicates that gender better predicts differences on the second dimension than it does on the first dimension. This finding is not surprising since the second dimension reveals more intraparty variance. These analyses support the widespread hypothesis that gender shapes legislative preferences and behaviors.

The pooled analysis indicates that gender differences emerge in both the first and second dimensions. Still, gender differences may not be present in each of the legislatures in my sample. To examine how widespread gender differences are, I estimate individual models for each of the 18 legislative chambers in my sample. Excluding the (now unnecessary) chamberlevel intercept as well as the chamber-level and session-level indicators, I use the same estimation technique as before to evaluate the difference in female-female dyads compared female-male dyads. ${ }^{9}$

Although the first dimension tends to represent sharp partisan divisions, gender differences between copartisans emerge in 8 of the 18 chambers (see Table 2). These findings may be surprising given the partisan nature of the first dimension. While the first dimension explains a large proportion of the variance in cosponsorship behavior, it is slightly less than half (see Table 2, row 7). The relatively small proportion of variance explained by the first dimension indicates that the ideal points

\footnotetext{
9. Given the small number of female legislators elected to each chamber, I do not limit this analysis to women within the same district for the chamber-level analysis of multimember districts. But I only consider the at-large portion of the mixed member districts.
} 
obtained from cosponsorship data are far from being one-dimensional and illustrates the value of looking beyond the first dimension.

The sixth column in Table 2 summarizes the results from the second dimension. Again, it is important to note that in each case the second dimension accounts for a significant amount of the variance. The proportion of variance explained in the second dimension ranges from .10 to .20 , indicating that in every chamber analyzed in my sample, cosponsorship behavior reveals a higher dimensionality than is typically revealed in analyses of roll call voting. This further illustrates how the lack of partisan and institutional structures (which influence roll call voting behavior) allows me to extract more information about legislators' preferences from cosponsorship behavior.

The analyses of the second dimension provide further support for my finding, revealing gender differences for eight additional chambers (i.e., Buenos Aires House, Chaco, Córdoba House, Córdoba Senate, Corrientes, Mendoza House, Salta, and Tucumán). The Federal District, Mendoza Senate, and Santa Cruz revealed gender differences in the first dimension but not in the second. In the case of the Federal District and Mendoza Senate, the coefficient was in the expected direction but not statistically significant. Santa Cruz, on the other hand, is an outlier in the sample. Historically, the PJ has dominated the Santa Cruz legislature. The influence of the PJ has been particularly pronounced since 2004. During the 2004-2007 period, the PJ occupied 85\% of the seats in the Santa Cruz legislature. During the 2008-2009 period, the PJ occupied $77 \%$ of the seats in the chamber. Given the small presence of the opposition, the same partisan cleavage that is present in the other legislative chambers does not dominate the first dimension. Instead, the first dimension reveals more intraparty heterogeneity than in other chambers and explains a larger proportion of the variance (.76). Considering this, it is not surprising that gender differences emerge in the first dimension and not in the second in the case of Santa Cruz.

Conversely, the Federal District has a higher than average party fragmentation, as compared to the other provinces. This may help explain why gender differences do not emerge in the second dimension in the Federal District. When there are more parties in the chamber, the partisan dynamics may not be as fully explained by the first dimension. As such, there may be less intraparty heterogeneity revealed in the second dimension. Less clear is why gender differences do not emerge in the second dimension of the Mendoza Senate. 
Overall, of 18 chambers in this analysis, there are statistically significant gender differences in all but two of the legislative chambers, Chubut and Formosa. In the case of Formosa, the coefficient is in the expected direction. In Chubut, the null finding may be a product of the small number of cosponsors who sign on to every bill. There are generally only two or three cosponsors (an average of 2.38 on each bill in this analysis) in Chubut. In other provinces, it is not uncommon to have bills with large groups of cosponsors. For example, in the Unicameral Chamber of Córdoba, where gender differences are quite apparent (see Figure 1), the number of cosponsors ranges from 2 to 28 with an average of 4.04 .

Finally, it is worth reiterating that the findings from this analysis are not a product of constituency characteristics or district demographics. Rather, gender differences are present in nine chambers that use at-large districts to elect legislators (i.e., Chaco, Córdoba House, Córdoba Unicameral, Corrientes House, Federal District, Misiones, Río Negro, Santa Fe, and Santa Cruz). In these chambers, each legislator represents the exact same district. Since constituency and district characteristics are held constant, we can be certain that these results are not driven by constituency differences.

The gender differences revealed in these analyses reflect women's propensity to promote shared interests by cosponsoring legislation. A female legislator from Río Negro, for instance, explained to me that women work together on issues that affect women. She noted that since everyone has different ideologies and perspectives, they discuss their points of view to develop legislation that better represents a range of women. She has worked frequently with female colleagues to address issues concerning women's health and violence against women and children. This type of collaboration is evident in most of the provinces. For example, after the protection against family violence law was passed in the National Congress in 1994, groups of women in provinces across Argentina, including Chaco, Córdoba, Río Negro, Misiones, Mendoza, Salta, and Santa Fe, formed coalitions within political parties (and in some cases even across parties [e.g., Río Negro and Santa $\mathrm{Fe}]$ ) to introduce legislation raising awareness about family violence and encouraging their province to adopt measures to comply with the national law. Women coalescing to promote issues of mutual concern, such as the protection against family violence law, are the types of behaviors that distinguish them in this analysis. 


\section{CONCLUSION}

Democratic theorists often debate the significance of descriptive representation and its importance for democracy. In particular, scholars of gender and politics are interested in understanding whether female legislators represent female constituents differently than their male colleagues. A key piece of this puzzle is understanding whether female legislators exhibit different legislative preferences than male legislators and the extent to which these differences are observable in their legislative behavior.

Extant research that examines this question produces mixed findings. I suggest that it is difficult to uncover gender differences in legislative preferences with roll call data because roll call behavior is highly structured by party influences. Since cosponsorship behavior is less structured by party pressures, cosponsorship data may be more appropriate for examining intraparty gender differences. Using a new dataset based on cosponsorship data from 18 Argentine provincial-level legislative chambers, I find that gender does indeed influence legislative preferences. I demonstrate that gender differences are present within political parties in approximately $90 \%$ of the legislative chambers in my sample. Differences in women's and men's cosponsorship behavior emerge as a product of women coalescing to promote shared interests, to galvanize support for important policies, and to raise awareness around issues that disproportionately exert an impact on women's lives. Cosponsoring legislation with colleagues who share similar priorities provides a venue for women in legislative bodies to exhibit distinct preferences over policy outcomes.

The finding that men and women exhibit different legislative preferences suggests that the disparity in the numeric representation of men and women throughout the world's legislatures might be problematic for the representation of women's interests. Where women do not comprise an equitable proportion of legislative chambers, their preferences are likely not being given adequate weight and their perspectives do not have a sufficient influence in the legislative process. This finding illustrates the importance of women's descriptive representation and further legitimizes efforts to increase women's presence in decision-making bodies.

Tiffany D. Barnes is Assistant Professor of Political Science at the University of Kentucky, Lexington, KY: tiffanydbarnes@uky.edu 


\section{REFERENCES}

Alemán, Eduardo, Ernesto Calvo, Mark P. Jones, and Noah Kapland. 2009. "Comparing Cosponsorship and Roll Call Ideal Points." Legislative Studies Quarterly 34 (1): 87- 116.

Balla, Steven J., and Christine L. Nemacheck. 2000. "Position-Taking, Legislative Signaling, and Non-Expert Extremism: Cosponsorship of Managed Care Legislation in the 105th House of Representatives." Congress and the Presidency 27 (2): 163-88.

Barnello, Michele A. 1999. "Gender and Roll Call Voting in the New York State Assembly." Women and Politics 20 (4): 77-94.

Barnes, Tiffany D., and Mark. P. Jones. 2011. "Women in Executives: Latin America” In Women in Executives: A Global Overview, eds. Gretchen Bauer and Manon Tremblay. New York: Routledge.

Bratton, Kathleen A., and Kerry L. Haynie. 1999. "Agenda Setting and Legislative Success in State Legislatures: The Effects of Gender and Race.” Journal of Politics 61 (3): 658-79.

Burrell, Barbara C. 1994. A Woman's Place is in the House: Campaigns for Congress in the Feminist Era. Ann Arbor: The University of Michigan Press.

Campbell, James. 1982. "Cosponsoring Legislation in the U.S. Congress." Legislative Studies Quarterly 7 (3): 415-22.

Carey, John. 2009. Legislative Voting and Accountability. Cambridge, MA: Cambridge University Press.

Chhibber, Pradeep, and Ken Kollman. 1998. "Party Aggregation and the Number of Parties in India and the United States." American Political Science Review 92 (2): 329-42.

Clark, Janet. 1998. "Women at the National Level: An Update on Roll-call Voting Behavior." In Women and Elective Office: Past, Present and Future, eds. Sue Thomas and Clyde Wilcox. New York: Oxford University Press.

Clinton, Joshua D., Simon D. Jackman, and Douglas Rivers. 2004. "The Statistical Analysis of Roll Call Data: A Unified Approach." American Political Science Review 98 (2): $355-70$.

Cox, Gary W., and Mathew D. McCubbins. 2005. Setting the Agenda: Responsible Party Government in the U.S. House of Representatives. Cambridge and New York: Cambridge University Press.

Crisp, Brian, Kristin Kanthak, and Jenny Leijonhufvud. 2004. "The Reputations Legislators Build: With Whom Should Representatives Collaborate?" American Political Science Review 98 (4): $703-16$.

De Luca, Miguel, Mark P.Jones, and MaríaInés Tula. 2002. “Back Rooms or Ballot Boxes? Candidate Nomination in Argentina." Comparative Political Studies 35 (4): 413-36.

De Riz, Liliana. 1996. "Argentina: Democracy in Turmoil." In Constructing Democratic Governance: South America in the 1990s, eds. Jorge I. Domínguez and Abraham F. Lowenthal. Baltimore, MD: Johns Hopkins University Press.

Desposato, Scott. 2004. "The Impact of Federalism on National Party Cohesion in Brazil." Legislative Studies Quarterly 29 (2): 259-85.

Fowler, James H. 2006. "Connecting the Congress: A Study of Cosponsorship Networks." Political Analysis 14 (4): 456-87.

Franceschet, Susan. 2011. "Gender Policy and State Architecture in Latin America." Politics \& Gender 7 (2): 273-79.

Franceschet, Susan, and Jennifer Piscopo. 2008. "Gender Quotas and Women's Substantive Representation: Lessons from Argentina.” Politics \& Gender 4 (3): 393-425.

Frankovich, Kathleen A. 1977. "Sex and Voting in the U.S. House of Representatives, 1961-1975." American Politics Quarterly 5 (3): 315-31. 
Gelman, Andrew, and Jennifer Hill. 2007. Data Analysis Using Regression and Multilevel/ Hierarchical Models. New York: Cambridge University Press.

Gibson, Edward L., and Ernesto Calvo. 2000. "Federalism and Low-Maintenance Constituencies: The Territorial Dimension of Economic Reform in Argentina." Studies in Comparative International Development 35 (5): 32-55.

Highton, Benjamin, and Michael Rocca. 2005. "Beyond the Roll-call Arena: The Determinants of Position Taking in Congress." Political Research Quarterly 58 (2): 303-16.

Hogan, Robert E. 2008. "Sex and the Statehouse: The Effects of Gender on Legislative RollCall Voting.” Social Science Quarterly 89 (4): 956-67.

Jones, Mark P. 2008. "The Recruitment and Selection of Legislative Candidates in Argentina." In Pathways to Power: Political Recruitment and Candidate Selection in Latin America, eds. Peter M. Siavelis and Scott Morgenstern. University Park: The Pennsylvania State University Press.

Jones, Mark P., and Wonjae Hwang. 2005a. "Party Government in Presidential Democracies: Extending Cartel Theory Beyond the U.S. Congress." American Journal of Political Science 49 (2): 267-83.

_. 2005b. "Provincial Party Bosses: Keystone of the Argentine Congress." In The Politics of Institutional Weaknesses: Argentine Democracy, eds. Steven Levitsky and María Victoria Murillo. University Park: The Pennsylvania State University Press.

Kessler, Daniel, and Keih Krehbiel. 1996. "Dynamics of Cosponsorship." The American Political Science Review 90 (3): 555-66.

Koger, Gregory. 2003. "Position-Taking and Cosponsorship in the U.S. House." Legislative Studies Quarterly 28 (2): 225-46.

Krehbiel, Keith. 1995. "Cosponsors and Wafflers from A to Z." American Journal of Political Science 39 (4): 906-23.

Leader, Shelah G. 1977. "The Policy Impact of Elected Women Officials." In The Impact of the Electoral Process, eds. Louis Maisel and Joseph Cooper. Beverly Hills, CA: Sage Publications.

Londregan, John. 2000. “Estimating Legislators' Preferred Points.” Political Analysis 8 (1): $35-56$.

McCarty, Nolan, Keith T. Poole, and Howard Rosenthal. 2001. “The Hunt for Party Discipline in Congress." American Political Science Review 95 (3): 673-88.

Mainwaring, Scott P. 1999. Rethinking Party Systems in the Third Wave of Democratization: The Case of Brazil. Stanford, CA: Stanford University Press.

Mansbridge, Jane. 1999. "Should Blacks Represent Blacks and Women Represent Women? A Contingent 'Yes." Journal of Politics 61 (3): 628-57.

Manzetti, Luigi. 1993. Institutions, Parties, and Coalitions in Argentine Politics. Pittsburgh, PA: University of Pittsburgh Press.

Martin, Andrew, and Kevin Quinn. 2002. "Dynamic Ideal Point Estimation via Markov Chain Monte Carlo for the U.S. Supreme Court, 1953-1999.” Political Analysis 10 (2): $134-53$.

Mayhew, David R. 1974. Congress: The Electoral Connection. New Haven, CT: Yale University Press.

Norton, Noelle H. 1997. “Analyzing Roll Call Voting Tools for Content: Are Women's Issues Excluded from Legislative Research?” Women and Politics 17 (4): 47-69.

Phillips, Anne. 1995. The Politics of Presence. Oxford: Clarendon Press.

Piscopo, Jennifer M. 2011. "Rethinking Descriptive Representation: Rendering Women in Legislative Debates." Parliamentary Affairs 11 (3): 1-25.

Pitkin, Hannah. 1967. The Concept of Representation. Berkley: University of California Press. 
Poggione, Sarah. 2004. "Exploring Gender Differences in State Legislators' Policy Preferences." Political Research Quarterly 57 (2): 305-14.

Poole, Keith. 2000. "Non-parametric Unfolding of Binary Choice Data." Political Analysis 8 (3): $211-37$.

Poole, Keith, and Howard Rosenthal. 1991. "Patterns of Congressional Voting." American Journal of Political Science 35 (1): 228-78.

— 1997. Congress: A Political Economic History of Roll Call Voting. New York: Oxford University Press.

— 2001. "D-Nominate after 10 Years: A Comparative Update to Congress: A PoliticalEconomic History of Roll-Call Voting.” Legislative Studies Quarterly 16 (1): 5-29.

Reingold, Beth. 1992. "Concepts of Representation among Female and Male State Legislators." Legislative Studies Quarterly 17 (4): 509-37.

Schwindt-Bayer, Leslie A. 2010. Political Power and Women's Representation in Latin America. Oxford: Oxford University Press.

Schwindt-Bayer, Leslie A., and Renato Corbetta. 2004. "Gender Turnover and Roll Call Voting in the U.S. House of Representatives." Legislative Studies Quarterly 29 (2): 215-29.

Shepsle, Kenneth A. 1979. "Institutional Arrangements and Equilibrium in Multidimensional Voting Models." American Journal of Political Science 23 (1): 27-60.

Sulkin, Tracy, and Nathaniel Swigger. 2008. "Is There Truth in Advertising? Campaign Ad Images as Signals about Legislative Behavior.” Journal of Politics 70 (1): 232-44.

Swers, Michele. L. 1998. "Are Women More Likely to Vote for Women's Issue Bills Than Their Male Colleagues?” Legislative Studies Quarterly 23 (3): 435-48.

_ 2002. The Difference Women Make. Chicago: The University of Chicago Press.

Talbert, Jeffery C., and Matthew Potoski. 2002. "Setting the Legislative Agenda: The Dimensional Structure of Bill Cosponsoring and Floor Voting." Journal of Politics 64 (3): 864-91.

Tatalovitch, Raymond, and David Schier. 1993. “The Persistence of Ideological Cleavage in Voting on Abortion Legislation in the House of Representatives, 1973-1988." American Politics Research 21 (1): 125-39.

Thomas, Sue. 1989. "Voting Patterns in the California Assembly: The Role of Gender." Women and Politics 9 (4): 43-53.

—. 1997. "Why Gender Matters: The Perceptions of Women Officeholders." Women and Politics 17 (1): 27-53.

Vega, Arturo, and Juanita M. Firestone. 1995. "The Effects of Gender on Congressional Behavior and Substantive Representation of Women." Legislative Studies Quarterly 20 (2): $213-22$.

Welch, Susan. 1985. "Are Women More Liberal Than Men in the U.S. Congress?" Legislative Studies Quarterly 10 (1): 125-34.

Wilson, Rick K., and Cheryl D. Young. 1997. "Cosponsorship in the United States Congress.” Legislative Studies Quarterly 22 (1): 24-43. 